\title{
TINDAK PIDANA NARKOTIKA SEBAGAI TRANSNASIONAL ORGANIZED CRIME
}

\author{
Roni Gunawan Raja Gukguk1*, Nyoman Serikat Putra J aya² \\ IFakultas Hukum, Universitas Riau \\ 2Fakultas Hukum, Universitas Diponegoro \\ ronigunawanrgg05@gmail.com
}

\begin{abstract}
Narcotics crime is an illegal act and is an organized crime. Narcotics crime is a transnational crime which is a form of transnational crime. This causes the development of narcotics crimes that occur in countries around the world to be completely eradicated. This study aims to determine the development of narcotics crime as one of the transnational crimes and to know the steps taken by the state in dealing with narcotics crimes. This study uses a normative approach. Narcotics abuse at the moment is very troubling for all humanity, because at this time narcotics is a scourge for all nations in general and the Indonesian people in particular.
\end{abstract}

\section{Keywords: Crime; Narcotics; Transnational.}

\begin{abstract}
ABSTRAK
Tindak pidana narkotika adalah suatu perbuatan melanggar hukum dan merupakan kejahatan yang terorganisir. Tindak pidana narkotika merupakan suatu kejahatan transnasional yang merupakan suatu bentuk kejahatan lintas batas negara. Hal ini menyebabkan perkembangan kejahatan narkotika yang terjadi di negara-negara didunia perlu untuk diberantas secara tuntas. Penelitian ini bertujuan untuk mengetahui perkembangan kejahatan narkotika sebagai salah satu kejahatan transnasional dan untuk mengetahui langkah yang dilakukan negara dalam menangani kejahatan narkotika. Penelitian ini menggunakan pendekatan normatif. Penyalahgunaan narkotika pada saat ini sangat meresahkan semua umat manusia, karena pada saat ini narkotika adalah sebuah momok bagi seluruh bangsa pada umumnya dan bangsa Indonesia pada khususnya.
\end{abstract}

Kata Kunci: Tindak Pidana; Narkotika; Transnasional.

\footnotetext{
${ }^{*}$ Corresponding Author
} 
Jurnal Pembangunan Hukum Indonesia

Volume 1, Nomor 3, Tahun 2019
Program Studi Magister Ilmu Hukum Fakultas Hukum Universitas Diponegoro

\section{A. PENDAHULUAN}

Perkembangan tindak kejahatan selama ini tidak hanya berada dalam suatu wilayah satu negara saja, melainkan juga telah melewati batas-batas wilayah negara-negara lainnya. Dalam beberapa tahun terakhir kita tentu tidak asing dengan peredaran narkotika dalam berbagai jenis di Indonesia, permasalahan ini adalah permasalahan yang serius yang harus dihadapi oleh pemerintah Indonesia, karena generasi kita sudah tentu harus dijamin oleh negara adalah sebuah generasi yang bebas pada jeratan narkotika, yang karenanya hanya dapat merusak masa depan suatu bangsa. Perlindungan kepada anak dalam suatu tindak pidana khususnya tindak pidana narkotika menjadi suatu hal yang penting, karena anak merupakan generasi penerus bangsa (Utami, 2014). Tindak kejahatan Narkoba (psikotropika, narkotika dan bahan zat adiktif lainya) sudah dapat dipastikan membahayakan kehidupan manusia, jika dikomsumsi dengan cara yang salah dapat mengakibatkan kematian bagi penggunanya (Eleanora, 2011) .

Perlindungan tindak pidana narkotika kepada anak perlu benar-benar diperhatikan karena anak merupakan bagian dari generasi muda sebagai salah satu sumber daya manusia yang merupakan potensi dan penerus perjuangan bangsa dimasa yang akan datang (Zahra, 2017). Perkembangan narkotika di Indonesia juga tidak lain karena adanya kejahatan internasional yang terorganisir dari luar negeri. Hukum pidana sendiri seharusnya memandang pelaku pengguna narkotika sebagai korban tindak pidana (Hafrida, 2016). Hal ini menunjukkan bahwa konstruksi yang dibangun oleh formulasi dalam UU No. 35 Tahun 2009 adalah bahwa pecandu dan korban penyalahgunaan narkotika diberi sanksi tindakan (rehabilitasi medis dan rehabilitasi sosial), sedangkan penyalahgunaan narkotika yang bukan pecandu diberi sanksi pidana. Parameter korban penyalahgunaan narkotika dalam UU No. 35 Tahun 2009 terlalu sempit dan sulit dibuktikan oleh tersangka/ terdakwa. Aparat penegak hukum menggunakan peraturan lain untuk menentukan parameter korban penyalahgunaan narkotika. Parameter tersebut adalah kondisi tertangkap tangan, ditemukan barang bukti narkotika untuk pemakaian 1 (satu) hari, positif menggunakan narkotika, dan tidak terdapat bukti terlibat dalam peredaran gelap narkotika (Arianti, 2018). Dalam kurun waktu beberapa tahun terakhir, telah banyak muncul kejahatan-kejahatan nasional yang juga telah menembus ruang dan batas internasional yang juga disebut sebagai suatu kejahatan transnasional.

Philip C. Jessup merupakan orang yang pertama kali memperkenalkan kejahatan transnasional disebutkan bahwa, selain istilah hukum internasional atau international law, digunakan pula istilah hukum transnasional atau transnational law yang disebut sebagai semua hukum yang mengatur semua tindakan atau kejadian yang melampaui batas teritorial suatu negara (Atmasasmita, 1997). International crime bisa juga disebut sebagai suatu bentuk kejahatan lintas batas negara dengan mencakup empat aspek, yakni: a). Locus delicti di 
Jurnal Pembangunan Hukum Indonesia

Volume 1, Nomor 3, Tahun 2019
Program Studi Magister Ilmu Hukum Fakultas Hukum Universitas Diponegoro lebih dari satu negara; b). Negara lain menjadi tempat persiapan, perencanaan, dan pengarahan serta pengawasan; c). Adanya keterlibatan kelompok kejahatan terorganisasi di mana kejahatan dilakukan di lebih satu negara dan; d). Berdampak serius pada negara lain (Serrano, 2002).

Permasalahan kejahatan tindak pidana narkotika telah menjadi permasalahan bangsa dan bangsa-bangsa di dunia yang selalu dibicarakan (Sudanto, 2017). Di dalam penetapan tindak pidana narkotika sebagai kejahatan dan pelanggaran dalam undang-undang pidana khusus memiliki implikasi yuridis materil dan yuridis formil (Supriyadi, 2015).

Perkembangan ilmu pengetahuan dalam prakteknya justru membawa peredaran dan penyalahgunaan narkotika ketahap atau tingkat yang lebih tinggi (Dofir, 2015). Dalam sejarahnya penggunaan narkotika pada awal tahun 2000 Sebelum Masehi sebagai alat untuk pelaksanaan upacara-upacara ritual dan juga digunakan untuk pengobatan. Narkotika pertama berjenis candu atau biasanya disebut "madat" atau "opium" (Atmasasmita, 1997). Indonesia yang semula menjadi negara transit atau pemasaran narkotika, sekarang sudah meningkat menjadi salah satu negara tujuan, bahkan telah pula merupakan negara eksportir atau negara produsen obat terlarang itu.

Hal ini terungkap dengan tertangkapnya tiga orang pria Indonesia di bandara Hongkong karena terbukti akan menyelundupkan Narkotika jenis ekstasi buatan Indonesia ke Cina. Pada periode 2017 sampai 2018, diperkirakan jumlah dari penyalahgunaan narkotika sudah sangat mengkhawatirkan dengan angka prevalensi penyalahgunaan narkotika setahun pakai pada kelompok pelajar sebanyak $3,21 \%$ atau setara dengan 2.297.492 orang sementara angka pravalensi setahun pakai dikalangan pekerja sebesar 2,1\% atau setara dengan 1.514.037 orang (Berita Sulsel, 2019).

Perkembangan penggunaan Narkotika dewasa ini yang semakin meningkat dan tidak untuk tujuan kepentingan pengobatan ilmu pengetahuan tetapi berbalik fungsi bertujuan memperoleh keuntungan yang sangat besar (Atmasasmita, 1997). Modus operandi tindak pidana Narkotika dengan cara menjerat sebanyak-banyaknya pemakai baru sebagai korban dan dilakukan secara terus menerus telah menjerumuskan pemakainya ke dalam kehidupan yang bersifat kontra produktif.

United Nations Convention Against Transnational Organized di Palermo tahun 2000 tentang Against Transnational Organized Crime menyebutkan bahwa bentuk anti toleransi yang dilakukan oleh Persatuan Bangsa Bangsa terhadap segala bentuk kejahatan transnasional. Dalam konteks negara-negara di kawasan Asia Tenggara, Association of South East Asian Nations (ASEAN) juga telah menyetujui untuk melakukan pemberantasan terhadap segala bentuk kejahatan transnasional yang terorganisir dengan munculnya ASEAN Ministerial Meeting on Transnational Crime (AMMTC) yang mendefinisikan mengenai 8 (delapan) bentuk kejahatan transnasional yang terorganisir yang terdiri dari: 1). Illicit Drug Trafficking (perederan 
Jurnal Pembangunan Hukum Indonesia

Volume 1, Nomor 3, Tahun 2019
Program Studi Magister Ilmu Hukum Fakultas Hukum Universitas Diponegoro gelap narkoba) ; 2). Trafficking in Person (perdagangan orang) ; 3). Sea Piracy (pembajakan laut) ; 4). Arms Smuggling (penyelundupan senjata);

5). Money Laundering (pencucian uang); 6). Terrorism (terorisme); 7). International Economic Crime (kejahatan ekonomi internasional) ; dan 8). Cyber Crime (kejahatan dunia maya) (Ariadno, 2009).

Kejahatan tindak pidana narkotika disebabkan oleh dua faktor, yang pertama faktor dalam diri pelaku kejahatan narkotika dan yang kedua faktor di luar diri pelaku kejahatan (Sulistyo, 2012). Kasus narkotika yang telah bersifat transnasional tentu menjadi sebuah kasus yang menarik untuk dikaji, mengenai hukum mana yang harus diterapkan dalam penanganan kasus tersebut, serta pihak berwenang manakah yang memiliki kewenangan dalam melakukan penegakan hukum dalam kasus tersebut.

Tujuan dari penelitian ini adalah untuk mengetahui perkembangan kejahatan narkotika sebagai salah satu kejahatan transnasional di dunia hingga saat ini. Dan juga untuk mengetahui langkah yang dilakukan negara Indonesia dalam menangani kejahatan narkotika yang terjadi secara transnasional.

Secara etimologis narkoba atau narkotika berasal dari Bahasa Inggris narcose atau narcosis yang berarti menidurkan dan pembiusan. Narkotika berasal dari Bahasa Yunani yaitu narke atau narkam yang berarti terbius sehingga tidak merasakan apaapa. Narkotika berasal dari perkataan narcotic yang artinya sesuatu yang dapat menghilangkan rasa nyeri dan dapat menimbulkan efek stupor (bengong), bahan-bahan pembius dan obat bius (Eleanora,2011) Dalam kamus besar Bahasa Indonesia pengertian narkotika atau narkoba adalah obat yang dapat menenangkan syaraf, menghilangkan rasa sakit, menimbulkan rasa kantuk atau merangsang.

Menurut istilah kedokteran, narkotika adalah obat yang dapat menghilangkan terutama rasa sakit dan nyeri yang berasal dari viresal atau alat-alat rongga dada dan rongga perut, juga dapat menimbulkan efek stupor atau bengong yang lama dalam keadaan yang masih sadar serta menimbulkan adiksi atau kecanduan (Anggreni, 2015).

Sejalan dengan perkembangan jaman, hukum berkembang mengikuti setiap kebutuhan manusia. Hukum terus mengalami perubahan guna perbaikanperbaikan di segala segi kehidupan manusia demi terwujudnya tujuan nasional (Dwiatmodjo, 2013).

Kejahatan tindak pidana narkotika yang saat ini perkembangannya sangat pesat ditambah dengan perkembangan dunia teknologi pada masa sekarang ini memberikan ancaman yang serius terhadap masing-masing Negara pada umumnya dan Negara Indonesia pada khususnya. Pengaturan tentang kejahatan tindak pidana narkotika ini harus lebih serius lagi mengingat kejahatan ini sudah menjadi kejahatan yang melintasi batas-batas wilayah Negara.

Dewasa ini permasalahan kejahatan narkotika sudah menjadi masalah yang sangat mengkhawatirkan Bangsa Indonesia, karena dengan adanya kejahatan ini banyak menimbulkan 
kejahatan-kejahatan, seperti pencurian, penelitian yang telah dilakukan oleh Melda Kamil permerkosaan, pembunuhan dan kejahatan lainnya. Ariadno, berfokus pada keamanan kejahatan laut di Ditambah dengan perkembangan teknologi pada asia tenggara (Ariadno, 2009). Berikutnya penelitian masa sekarang ini, kejahatan narkotika sudah menjadi kejahatan yang terorganisir antara negara yang satu dengan negara yang lain tanpa melihat batas antar negara.

Dari permasalahan di atas, maka yang menjadi pokok permasalahan dalam artikel ini adalah: pertama, bagaimana perkembangan kejahatan narkotika sebagai salah satu kejahatan transnasional di Indonesia hingga saat ini?; dan kedua, bagaimana langkah yang dilakukan Negara Indonesia dalam menangani kejahatan narkotika yang terjadi secara transnasional?

Berdasarkan penelitian yang berfokus pada kejahatan narkotika yang telah dilakukan sebelumnya seperti oleh Bayu Puji Harianto, penelitian tersebut berfokus pada pencegahan dan pemberantasan kejahatan tindak pidana narkotika (Harianto, 2018). Penelitian yang telah dilakukan sebelumnya oleh Fransiska Novita Eleanora, penelitian tersebut berfokus pada bahaya dan penanggulangan kejahatan tindak pidana narkotika (Elenora, 2011). Kemudian Anton Sudanto, dalam penelitiannya berfokus pada penerapan kejahatan tindak pidana narkotika di Indonesia (Sudanto, 2017). Pada tingkat internasional penelitian yang telah dilakukan oleh Andriani Kusumaningrum, penelitian tersebut memfokuskan pada upaya Negara Negara di ASEAN dalam memberantas kejahatan lintas Negara seASEAN (Kusumaningrum, 2013). Berikutnya terhadap permasalahan narkotika yang dilakukan oleh Glenn E. Curtis, membahas lebih dalam mengenai hubungan antara kejahatan terorisme, perdagagangan narkotika dan penyelundupan senjata yang dilakukan oleh jaringan yang teroganisir di Eropa Barat (Curtis, 2002). Sedangkan penelitian lainnya yang dilakukan oleh Svante E. Cornell, berfokus untuk membahas hubungan antara Narkotika dan Konflik yang terjadi pada beberapa negara di dunia (Cornell, 2005).

Maka berdasarkan tulisan sebelumnya, terdapat perbedaan fokus penelitian yang akan dilakukan oleh penulis dengan penelitian yang sudah ada. Walaupun sama-sama mengambil tema tentang Kejahatan Narkotika, namun penulis lebih menekankan pada Kejahatan Narkotika Sebagai Transnasional Organized Crime, sehingga membuat pembahasan mengenai hal ini menjadi hal yang selalu penting dan aktual untuk dilakukan pengkajian" lebih lanjut.

\section{B. METODE PENELITIAN}

Penelitian yang digunakan adalah penelitian doktrinal, di mana pada penelitian ini menggunakan suatu metode penelitian hukum normatif (normative legal research). Data "yang dipergunakan adalah data sekunder, yaitu data yang diperoleh secara tidak langsung sumbernya atau objek penelitiannya berupa bahan hukum primer, sekunder dan tersier" (Suteki, 
Jurnal Pembangunan Hukum Indonesia

Volume 1, Nomor 3, Tahun 2019
Program Studi Magister Ilmu Hukum Fakultas Hukum Universitas Diponegoro
\& Taufany, 2018). Pengumpulan data di dalam memecahkan permasalahan ini, dilakukan dengan studi kepustakaan (library research), yang kemudian dianalisis secara kualitatif. Teknik analisis ini merupakan teknik yang mana bahan-bahan atau literatur-literatur hukum tersebut akan dipelajari sehingga dapat memberikan gambaran-gambaran tentang topik penelitian sehingga membantu penulis membuat suatu kesimpulan yang benar.

\section{HASIL DAN PEMBAHASAN}

\section{Perkembangan Kejahatan Narkotika}

Perkembangan kejahatan narkotika sebagai salah satu kejahatan transnasional di dunia pada saat ini sangat mempengaruhi perkembangan segala aspek dalam kehidupan bermasyarakat. Dalam salah satu literatur disebutkan bahwa "Transnational is defined as any activity that originates from within society (rather than from within the decision structure and resources of the state) is commisioned and undertaken by agents operating in several national jurisdictions and is transmitted or replicated across national borders" (Kusumaningrum, 2013) atau kejahatan lintas negara diartikan sebagai sebuah kejahatan yang dilakukan secara terorganisir dan terdapat lebih dari satu yurisdiksi nasional yang dilanggar.

Kejahatan transnasional atau Transnational Organized Crime (TOC) adalah fenomena jenis kejahatan yang melintasi perbatasan internasional, melanggar hukum beberapa negara atau memiliki dampak terhadap negara lain. Salah satu bentuk
TOC berupa perdagangan narkotika yang dilakukan secara global. Hal ini disebabkan karena perdagangan narkotika tersebut melintasi batas wilayah suatu negara, sehingga mengaburkan batas - batas suatu wilayah. Permasalahan perdagangan narkotika dapat mengancam kedaulatan politik suatu negara karena kapasitas kegiatannya mampu melemahkan otoritas dan legitimasi pemerintahan di suatu negara.

Hal ini telah menjadi persoalan besar, tidak hanya di tingkat nasional Indonesia sendiri tetapi juga telah menjadi bagian dari masalah yang serius dalam taraf internasional. Menurut catatan terbaru dari World Drug Report tahun 2018, total pengguna narkotika di seluruh dunia semenjak tahun 2016 meninggal dunia sebanyak 450.000 jiwa (UNODC, 2018).

Peredaran gelap narkotika di kawasan Asia Tenggara memiliki dua rute utama peredaran, yakni rute selatan melalui Thailand menuju Bangkok untuk alur distribusi dan jalur utara yang memasuki daerah Provinsi Yunnan di Tiongkok, kemudian menuju Kunming dan selanjutnya menyebar ke kawasan lain. Menurut Laporan United Nations Office on Drugs and Crime tahun 2016, hasil laporan tersebut menyebutkan bahwa, produksi dan peredaran gelap Narkotika paling dominan muncul di sekitar kawasan Laos, Myanmar dan Thailand yang memiliki julukan sebagai "Segitiga Emas" bersama dengan Tiongkok. "Segitiga Emas" merupakan istilah bagi salah satu kawasan yang paling mendominasi arus peredaran 
Jurnal Pembangunan Hukum Indonesia

Volume 1, Nomor 3, Tahun 2019
Program Studi Magister Ilmu Hukum Fakultas Hukum Universitas Diponegoro narkotika yang membanjiri pasar global dalam rentang beberapa tahun terakhir.

Hal ini secara otomatis menurut penulis menempatkan kawasan Asia Tenggara sebagai kawasan dengan tingkat produksi, penyalahgunaan dan peredaran gelap narkotika terbesar kedua di dunia setelah kawasan Amerika Utara. Di samping itu, tindak pidana narkotika yang terjadi dalam arus lintas negara di suatu kawasan/regional tertentu, dalam aspek apapun (baik itu produksi, penyalahgunaan dan peredaran gelap), seperti yang terjadi di negara Meksiko.

Perkembangan kejahatan narkotika sebagai TOC di negara Meksiko, terkenal sebagai salah satu negara penyuplai narkotika ke negara Amerika Serikat. Hal ini disebabkan karena hampir 70\% narkotika jenis ganja, heroin, dan methamphetamine di Amerika Serikat berasal dari Meksiko. Selain itu, Meksiko juga terkenal sebagai negara transit karena Meksiko menyuplai sekitar 90\% narkotika jenis kokain yang berasal dari Kolombia, Bolivia, Peru ke Amerika Serikat (Sindonews, 2018) Tidak hanya melakukan perdagangan narkotika saja tetapi Bandar narkotika dari meksiko juga melakukan tindakan kriminalitas lainnya seperti pemerasan, pembunuhan, juga menmbulkan instabilitas keamanan di sepanjang perbatasan Amerika Serikat dan Meksiko.

Semua tindakan kriminal Bandar-bandar narkotika asal Meksiko memberikan ancaman tidak hanya kepada masyarakat di kedua sisi perbatasan, tetapi juga kepada keamanan nasional Amerika Serikat (Sepper, \& Conery,2010).
Peredaran narkotika melalui Meksiko ke Amerika Serikat ini dikuasai oleh TOC berbentuk kartel. Kartel merupkan organisasi kejahatan yang bertugas memasarkan dan mengendalikan peredaran narkotika baik di dalam negaranya maupun di negara lain.

Dalam ruang lingkup Indonesia sendiri, berdasarkan data yang dimiliki Badan Narkotika Nasional disebutkan bahwa, tidak satupun Kota/kabupaten di Indonesia yang terbebas dari masalah narkoba.

Apabila sebelumnya penyelundupan narkoba lebih banyak dilakukan melalui jalur udara, tetapi untuk saat ini jalur laut banyak dipakai oleh pelaku penyelundupan narkoba untuk memasukkan barangnya ke wilayah Indonesia. Salah contoh kasus yang ditangani oleh BNN satu unit kapal motor berhasil diamankan oleh petugas gabungan di perairan Aceh Tamiang pada 19 Agustus 2018. Di dalam kapal tersebut ditemukan 70 bungkus sabu seberat $73,5 \mathrm{~kg}$ dan 30ribu pil ekstasi dari Malaysia. (CNN, 2018)

Transaksi narkoba di tengah laut merupakan transaksi narkotika yang paling aman, hal ini karena pengawasan di tengah laut dengan jumlah petugas yang sangat minim atau hampir tidak ada yang menyebabkan mudahnya transaksi narkotika melalui jalur laut.

Salah satu pemasok narkoba ke Indonesia adalah Tiongkok, karena Tiongkok merupakan salah satu pemasok narkoba yang besar dan salah satu sumber utama narkoba di Indonesia. Maka Indonesia 
Jurnal Pembangunan Hukum Indonesia

Volume 1, Nomor 3, Tahun 2019
Program Studi Magister Ilmu Hukum Fakultas Hukum Universitas Diponegoro dengan Tiongkok membuat kesepakatan kerjasama pemberantasan yang diperlukan sebagai pegangan atau acuan oleh BNN dalam pemberantasan narkoba dari Tiongkok (Wardani, Utomo, \& Wahyudi 2018).

Pasar narkoba yang besar dan menguntungkan di Indonesia menyebabkan sindikat internasional, termasuk dari Malaysia, melakukan berbagai upaya untuk menyelundupkan narkoba ke Indonesia. Berbagai modus ditempuh oleh para penyelundup untuk memasukkan barang haramnya tersebut ke Indonesia melalui jaringan lintas batas negara.

Penyelundupan narkoba semakin giat dilakukan oleh sindikat internasional dengan melintasi daerah-daerah di Indonesia yang langsung berbatasan dengan beberapa negara tetangga, seperti wilayah Kepulauan Riau dan wilayah Provinsi Kalimantan Barat yang juga berbatasan langsung dengan Malaysia.

Hal ini menunjukkan bahwa sindikat narkoba internasional, dengan jaringan lintas batasnya, tidak bisa diabaikan keberadaannya dan perlu pengawasan serta pencegahan yang lebih maksimal dari aparat penegak hukum, di samping dibutuhkannya peraturan serta penegakan hukum yang lebih tegas dalam upaya untuk memberantas peredaran narkotika.

Terjadinya penyelundupan narkoba yang dilakukan oleh sindikat internasional melalui wilayah Kepulauan Riau dan Kalimantan Barat yang berbatasan dengan wilayah Malaysia menunjukkan bahwa masih ada kelemahan dari aparat yang melakukan pengawasan di pos-pos pemeriksaan lintas batas, salah satu kelemahan adalah keterbatasan penggunaan teknologi (alat pendeteksi, contohnya: Pendeteksi Narkoba jenis GT 200) jika penyelundupan dilakukan melalui jalur resmi (baik bandara maupun pelabuhan). GT 200 dapat digunakan untuk mendeteksi beberapa jenis narkoba yaitu heroin, opium, cannabis dan ekstasi.

\section{Langkah Dalam Menangani Kejahatan Narkotika}

Pencegahan atau penanggulangan

penyalahgunaan narkotika merupakan suatu upaya yang ditempuh dalam rangka penegakan baik terhadap pemakaian, produksi maupun peredaran gelap narkotika yang dapat dilakukan oleh setiap orang baik individu, masyarakat dan negara (Harianto, 2018).

Pengaturan hukum dengan skala internasional mengenai peredaran gelap narkotika pertama kali dirumuskan dalam The United Nation's Single Convention on Narcotic Drugs Tahun 1961 yang kemudian diamandemen pada tahun 1972 dengan Protokol tentang Perubahan atas United Nation's Single Convention on Narcotic Drugs Tahun 1961. Perbedaan The United Nation's Single Convention on Narcotic Drugs dengan United Nations Convention against Transnational Organized Crime adalah Konvensi The United Nation's Single Convention on Narcotic Drugs Tunggal ini pada awalnya dibentuk dengan maksud untuk: 1). Menyempurnakan suatu strategi pengawasan terhadap peredaran narkotika 
Jurnal Pembangunan Hukum Indonesia

Volume 1, Nomor 3, Tahun 2019
Program Studi Magister Ilmu Hukum Fakultas Hukum Universitas Diponegoro dan juga membatasi penggunaannya, diperbolehkan digunakan hanya dikhususkan untuk kepentingan medis dan untuk pengembangan suatu ilmu pengetahuan; dan 2). Menjamin suatu kerjasama internasional melalui strategi pengawasan terhadap peredaran narkotika untuk tujuan yang sebagimana disebutkan diatas (Rukmana, 2014).

Selain penjelasan di atas terdapat pula beberapa konvensi internasional lainnya yang juga berkaitan dengan permasalahan Narkotika ini, yakni United Nation's Convention Against Illicit Traffic in Narcotic Drugs and Psychotropic Substances 1988 dan United Nations Convention against Transnational Organized Crime. Implikasi dari konvensi tersebut adalah penandatanganan deklarasi negara-negara ASEAN tentang prinsip-prinsip pemberantasan penyalahgunaan narkotika oleh masing-masing Menteri Luar Negeri dari tiap negara se-ASEAN pada tahun 1976 di Manila, yang menyebutkan bahwa, secara umum menyepakati beberapa hal, yakni: a). Kesamaan pendekatan dan cara pandang, serta juga strategi dalam penanggulangan kejahatan narkotika; b). Keseragaman dalam hal peraturan perundangundangan di bidang narkotika; c). Membentuk suatu badan koordinasi dalam tingkat nasional masingmasing negara; dan d). Me njalin kerjasama antar negara-negara se-ASEAN secara bilateral, regional dan juga internasional.

Upaya awal ASEAN dalam memerangi kejahatan transnasional difokuskan pada penyalahgunaan dan peredaran gelap narkotika yang mana sangat mempengaruhi pertumbuhan dan perkembangan negaranegara ASEAN pada saat itu (Rukmana, 2014).

Selain menyepakati Deklarasi tersebut, Negara-negara ASEAN sepakat untuk dibentuknya organisasi Narcotic Board. Narcotic Board diharapkan dapat sesuai dengan karakteristik permasalahan narkotika dan penegakan hukum di masing-masing negara, yang mana pada akhirnya menjadi cikal bakal kelahiran Badan Narkotika Nasional Republik Indonesia (BNN RI).

United Nations Convention against Transnational Organized Crime (UNCTOC) tahun 2016 sebagai sarana dalam menciptakan perjanjian internasional yang bersifat law making treaties. Pada UNCTOC, tidak diatur secara rigid pengertian dari "transnational organized crime" dan tidak juga memuat daftar tindak pidana yang dapat digolongkan ke dalamnya.

Hal tersebut kemungkinan disebabkan dengan aturan hukum yang berlaku di setiap Negara, seperti contoh penggunaan narkotika jenis Sabu-Sabu dilegalkan di California, Amerika Serikat, sedangkan perdagangan narkotika jenis Sabu-Sabu dilarang oleh pemerintah Indonesia.

Penggunaan zat adiktif berupa kokain dalam tahun 2016 tersebut, dilakukan oleh hampir 470.000 (empat ratus tujuh puluh ribu) orang. Untuk zat dengan jenis Amphetamine mencapai 9.100.000 (sembilan juta seratus ribu) pengguna dan untuk ekstasi mencapai angka 3.210 .000 (tiga juta dua ratus sepuluh ribu) orang (Rukmana, 2014). 
Jurnal Pembangunan Hukum Indonesia

Volume 1, Nomor 3, Tahun 2019
Program Studi Magister Ilmu Hukum Fakultas Hukum Universitas Diponegoro
Polri dalam upaya pencegahan dan penanggulangan narkotika, melakukan langkah langkah strategis sebagai berikut : yang pertama secara Pre-emptif yang dilakukan adalah berupa kegiatan-kegiatan edukatif (pendidikan/pengajaran) dengan tujuan mempengaruhi faktor-faktor penyebab yang mendorong dan faktor peluang, yang biasa disebut sebagai faktor "korelatif kriminologen" dari kejahatan narkotika, sehingga tercipta kesadaran, kewaspadaan, daya tangkal, serta terbina serta terciptanya kondisi perilakul norma hidup bebas tanpa narkotika. Kegiatan yang bersifat preventif edukatif dilakukan dengan metode komunikasi informasi edukatif, yang dilakukan melalui berbagai cara yaitu antara lain keluarga, pendidikan, lembaga keagamaan, dan organisasi kemasyarakatan. Yang kedua adalah upaya preventif dimana upaya ini dilakukan untuk mencegah terjadinya kejahatan narkotika melalui pengendalian dan pengawasan jalur resmi serta pengawasan langsung terhadap jalur-jalur pereddaran gelap dengan tujuan agar police hazard tidak berkembang menjadi ancaman factual, dan upaya reprefif atau penindakan terhadap kejahatan narkotika dilakukan dengan cara penangkapan terhadap pengguna dan pengedar narkoba. Pengkapan tidak hanya dilakukan terhdapa warga negara Indonesia saja, tetapi penangkapan juga dilakukan terhadap warga negara asing yang terlibat. ( UU No.2 Tahun 2002)

Dalam upaya pencegahan terhadap tindak pidana narkotika negara Indonesia juga melakukan hubungan bilateral dengan berbagai negara untuk memastikan bahwa negara Indonesia aman dari bahaya narkotika

Selain kerja sama secara bilateral, kerja sama secara multilateral di antara negara-negara ASEAN juga perlu dilakukan untuk memberantas penyelundupan dan perdagangan narkotika di wilayah regional Asia Tenggara. Indonesia, Singapura dan Malaysia serta negara-negara lain, anggota ASEAN, perlu meningkatkan kerja sama dalam memerangi bahaya ancaman narkoba.

Penyelundupan dan perdagangan gelap narkoba yang sudah sangat mengancam masyarakat ASEAN harus diatasi secara sungguh-sungguh, terlebih ASEAN sendiri sudah berkomitmen untuk mewujudkan "ASEAN Bebas Narkoba 2015". Sebuah komitmen yang tidak mudah untuk diwujudkan, termasuk oleh Indonesia yang transaksi narkobanya tertinggi se-ASEAN. BNN, pada bulan Januari 2015, menyatakan bahwa transaksi narkoba yang ada di Indonesia menduduki peringkat tertinggi (sekitar 40 persen) dibandingkan dengan negara-negara yang tergabung dalam organisasi ASEAN lainnya (Liputan6, 2015)

Masalah pidana dan pemidanaan dalam sejarah selalu mengalami perubahan (Kansil, 2014). Hal demikian juga dialami dalam perubahan undang undang tentang narkotika yang masa sebelumnya Indonesia menggunaan Undang-undang Nomor 22 Tahun 1997 yang diubah dengan Undang-Undang Nomor 25 Tahun 2009. Di dalam Undang-undang yang baru ini, pemerintah bertujuan antara lain menjamin ketersediaan narkotika untuk kepentingan 
Jurnal Pembangunan Hukum Indonesia

Volume 1, Nomor 3, Tahun 2019
Program Studi Magister Ilmu Hukum Fakultas Hukum Universitas Diponegoro pelayanan kesehatan dan atau pengembangan ilmu pengetahuan dan teknologi; mencegah, melindungi dan menyelamatkan bangsa Indonesia dari penyalagunaan narkotika; memberantas peredaran gelap narkotika; dan menjamin pengaturan upaya rehabilitasi medis dan sosial bagi penyalahguna dan pecandu narkotika.

Selain menerapkan Undang-Undang Nomor 35 Tahun 2009 tentang Narkotika, pemerintah juga memperkuat aturan hukum tersebut melalui Peraturan Pemerintah Nomor 25 Tahun 2011 tentang Pelaksanaan Wajib Lapor Pecandu Narkotika. Tidak hanya itu, pemerintah juga mengeluarkan Intruksi Presiden Nomor 6 Tahun 2018 tentang Rencana Aksi Nasional Pencegahan Dan Pemberantasan Penyalahgunaan Dan Penggelapan Narkotika Dan Prekursor Narkotika tahun 2018-2019, sebagai bentuk komitmen bersama seluruh komponen masyarakat, bangsa dan negara. Terakhir adalah Peraturan Menteri Dalam Negeri Nomor 12 tahun 2019 tentang Fasilitasi Pencegahan Dan Pemberantasan Penyalahgunaan Dan Peredaran Gelap Narkotika Dam Prekursor Narkotika, yang di dalamnya melibatkan peran serta dari gubernur/bupati/walikota.

Transaksi narkoba di wilayah ASEAN pertahun mencapai sekitar Rp110 triliun dan di Indonesia sendiri berkisar Rp48 triliun (Rumah Cemara, 2019). Masalah penyelundupan narkoba bagi Indonesia dari Malaysia juga harus menjadi bagian dari perhatian ASEAN untuk menanggulanginya. Sebagai upaya bersama ASEAN dalam meningkatkan upaya penanggulangan masalah narkoba, telah dibentuk sebuah forum khusus di tingkat kementerian yang menangani permasalahan narkoba yang disebut dengan Asean Ministerial Meeting on Drug Matters (AMMDM).

Dalam pertemuan tahunannya yang ketiga di Jakarta, bulan Desember 2014, peserta AMMDM telah bersepakat antara lain bahwa dalam penanganan masalah narkoba lintas batas, selain perlu dilakukan upaya penguatan kerja sama secara regional, kerja sama secara bilateral diantara negaranegara ASEAN, khususnya yang saling berbatasan, juga penting untuk terus diperkuat, terutama dengan membuat rencana aksi bersama guna mengatasi masalah penyelundupan narkoba lintas batas di kawasan perbatasan. Ini artinya, dalam kerangka penanganan kasus penyelundupan narkoba di Kepri dan Kalbar (yang berbatasan langsung dengan Malaysia), kerja sama bilateral Indonesia - Malaysia menjadi suatu keharusan untuk dilakukan dan ditingkatkan. Dalam kerangka itu pula, langkahlangkah koordinasi dengan berbagi informasi dan praktik terbaik dalam rangka meningkatkan penegakan hukum yang lebih efektif dalam pengendalian narkoba di masing-masing wilayah juga harus menjadi bagian penting dari kerja sama bilateral Indonesia - Malaysia dan kerja sama multilateral diantara negara-negara ASEAN. Negaranegara ASEAN perlu saling bertukar strategi dan mengetahui tindak pidana narkoba di wilayah ASEAN. 
Jurnal Pembangunan Hukum Indonesia

Volume 1, Nomor 3, Tahun 2019
Program Studi Magister Ilmu Hukum Fakultas Hukum Universitas Diponegoro
Negara-negara ASEAN perlu memperkuat kebijakan dan pemahaman bersama terkait pencegahan dan penekanan peredaran narkoba di kawasan Asia Tenggara. Kerja sama dan koordinasi secara komprehensif dengan mitra dialog dan pihak eksternal juga harus ditingkatkan. Di bidang perundang-undangan, harmonisasi regulasi mengenai pemberantasan narkoba juga perlu diakukan oleh negara-negara ASEAN.

Terkait harmonisasi regulasi, ASEAN dapat memanfaatkan forum AIFOCOM (AIPA Fact Finding Committee to Combat the Drug Menace), sebuah forum antarparlemen negara-negara ASEAN yang secara khusus dibentuk untuk membahas permasalahan narkoba di kawasan Asia Tenggara. Pentingnya harmonisasi legislasi terkait pemberantasan narkoba diantara negara-negara ASEAN kembali ditegaskan dalam pertemuan AIFOCOM ke-11 di Vientiene, Laos, bulan Mei 2014. Parlemen negara-negara anggota ASEAN sepakat bahwa mereka akan memperkuat legislasi nasional masing-masing untuk memerangi kejahatan peredaran gelap narkoba.

Pencegahan atau penanggulangan penyalahgunaan narkotika merupakan suatu upaya yang ditempu dalam rangka penegakan baik terhadap pemakaian, produksi maupun peredaran gelap narkotika yang dapat dilakukan oleh setiap individu, masyarakat dan negara. Dalam upaya penanggulangan kejahatan ada tiga elemen pokok yang harus diperhatikan yang pertama yaitu penerapan hukum pidananya, yang kedua pencegahan tanpa pidana dan mempengaruhi pandangan masyarakat mengenai kejahatan dan pemidanaan lewat media massa (Helviza,2016).

Dalam rangka melakukan upaya pencegahan dirasa perlu memperhatikan beberapa aspek berikut; yang pertama adalah sarana dan prasarana dalam upaya pencegahan terjadinya kejahatan narkotika yang melewati batas lalu lintas negara, karena saat ini sarana dan prasarana di Indonesia sangat tidak mendukung dengan kondisi di lapangan. Sarana dan prasarana yang dimaksud antara lain penyediaan teknologi (GT 200) merupakan sebuah alat teknologi khusus yang mampu mendeteksi narkotika ketika melalui pemeriksaan alat tersebut yang dapat dengan mudah mendeteksi keberadaan narkotika yang melewati lintas batas negara, penambahan armada laut saat diperluan didalam upaya pencegahan masuknya narkotika dari jalur laut, mengingat Indonesia merupakan negara kepulauan yang memiliki banyak jalur laut yang dapat dilalui oleh para pelaku tindak pidana narkotika; kedua proses penegakan hukum yang selama ini terjadi dindonesia masih dianggap penulis sebagai upaya penegakan hukum yang setengah-setengah karena tidak ada penentuan pasti kapan waktu para narapidana narkotika yang diputus pengadilan dengan pidana mati, namun waktu penentuan dilakukan eksekusi pidana mati masih mengambang. Maka dari itu menurut penulis dibutuhkan pengaturan yang pasti tentang pelaksanaan penegakan hukum terhadap pelaku tindak pidana narkotika; yang ketiga pengawasan dan penegakan terhadap oknum-oknum 
penegak hukum yang menyalahgunaan wewenangnya dalam keterlibatan peredaran dan penyalahgunaan narkotika di Indonesia. Dan yang paling penting adalah peran dan partisipasi oleh seluruh masyarakat Indonesia pada umumnya dan masyarakat wilayah perbatasan pada khususnya. Peran masyarakat dapat diwujudkan dengan melaporkan adanya aktivitas yang mencurigakan yang patut dapat diduga merupakan suatu tindak pidana narkotika.

\section{SIMPULAN}

Kejahatan narkotika merupakan suatu kejahatan transnasional yang saat ini menjadi suatu kejahatan lintas negara yang terjadi di indonesia. Kejahatan narkotika saat ini sudah menjadi momok yang besar bagi Negara Indonesia, kejahatan narkotika juga merupakan kejahatan lintas negara yang terorgansir. Oleh sebab itu dibutuhkan keseriusan Pemerintah Indonesia dalam hal memerangi atau memberantas kejahatan narkotika ini.

Pemerintah Indonesia saat ini telah memiliki peraturan untuk mengatasi masalah kejahatan narkotika dengan adanya Undang-undang Nomor 35 Tahun 2009 tentang Narkotika. Walaupun telah ada peraturan yang mengatur tentang kejahatan narkotika di Indonesia, ternyata sampai saat ini tidak menjadi jawaban untuk masalah ini karena kejahatan narkotika merupakan kejahatan yang para pelaku tindak pidana ini selalu memiliki cara khusus untuk terus melakukan aksinya. Dibutuhkan lagi keseriusan oleh aparat penegak hukum untuk mengatasi kejahatan ini. Aparat penegak hukum beserta seluruh masyarakat Indonesia dianggap perlu dengan serius dalam memerangi kejahatan tindak pidana narkotika demi generasi yang baik untuk Indonesia kedepannya.

Langkah-langkah yang perlu ditempuh untuk mengatasi kejahatan tindak pidana narkotika sebagai kejahatan transnasional di Indonesia antara lain sebagai berikut; peningkatan sarana dan prasana berupa alat pendeteksi (GT200) dan penambahan armada laut milik Indonesia dalam rangka penegakan hukum; dibutuhkannya kepastian hukum dalam penegakan tindak pidana narkotika, yang melintasi setiap wilayah perbatasan yang ada dalam wilayah kesatuan republik Indonesia; peran aktif dari masyarakat untuk terlibat melaporkan kepada pihak yang berwenang.

\section{DAFTAR PUSTAKA}

\section{BUKU}

Atmasasmita, R. (1997). Tindak Pidana Narkotika Transnasional dalam Sistem Hukum Pidana Indonesia. Bandung: Citra Aditya Bhakti.

Serrano, M. (2002). Transnational Organized Crime and International Security: Business as Usual. Colorado: Lynne Rienner Publishers.

Suteki., \& Taufani, Galang. (2018). Metodologi Penelitian Hukum (Filsafat, Teori Dan Praktik). Depok: PT RajaGrafindo Persada. 
Jurnal Pembangunan Hukum Indonesia

Volume 1, Nomor 3, Tahun 2019
Program Studi Magister Ilmu Hukum Fakultas Hukum Universitas Diponegoro

\section{JURNAL}

Wardani, Ella Aditya., Utomo, Tri Cahyo., Wahyudi, Fendy Eko. (2018). Analisis Kepatuhan Dalam Implementasi Kerjasama Indonesia-Tiongkok Menangani Kasus Penyelundupan Narkoba Melalui Jalur Laut Pada Tahun 2012-2015. J ournal of International Relations Universitas Diponegoro Semarang, Vol.4, (No.2),pp. 198206.

Anggreni, D. (2015). Dampak Bagi Pengguna Narkotika, Psikotropika Dan Zat Adiktif (Napza). E-Jurnal Sosiatri-Sosiologi, Vol.III, (No.3), pp.37-51.

Cornell, Svante E. (2005). The Interaction of Narcotics and Conflict. Journal of Peace Reasecrh, Central Asia-Caucasus Institute, Vol. 42 issue: 6, pp. 751-760.

Curtis, Glenn E. (2002). The Nexus Among Terrorist , Narcotics Traffickers, Weapons Proliferators, and Organized Crime Network in Western Europe. J ournal of The Library of Congress Federal Reaserch Division. Washington D.C, pp. 1-26.

Dwiatmodjo, H. (2013). Pelaksanaan Dan Pembinaan Narapidana Tindak Pidana Narkotika. J urnal Hukum Perspektif, Vol.XVIII, (No.2), pp.64-72.

Hafrida. (2016). Kebijakan Hukum Pidana Terhadap Pengguna Narkotika Sebagai Korban Bukan Pelaku Tindak Pidana. Jurnal Hukum Padjajaran, Vol.III, (No.1),pp.173-191.

Helviza, I. (2016). Kendala-Kendala Badan Narkotika Nasional (BNN) Dalam Penanggulangan
Penyalahgunaan Narkotika di Kota Banda Aceh. Jurnal IImiah Mahasiswa Pendidikan Kewarganegaraan Unsiah, Vol.1, (No.1), pp.129-143.

Ariadno, Melda K. (2009). Maritime Security In South East Asia: Indonesian Perspective. Indonesian Journal of International Law (IJ IL), Vol.7, (No.1), pp.88-96.

Kansil, Fernando L. (2014). Sanksi Pidana Dalam Sistem Pemidanaan Menurut KUHP dan Diluar KUHP. Jurnal Lex Crimen. Vol III, (No.3), pp.26-34

Kusumaningrum, A. (2013). The Asean Political Security Community: Asean Security Cooperation on Combatting Transnasional Crimes and Transboundary Challenges. Indonesian Journal of International Law (IJ IL), Vol.11, (No.1), pp. 89-102.

Eleanora, Fransiska N. (2011). Bahaya Penyalahgunaan narkoba serta usaha pencegahan dan penanggulangannya. J urnal Hukum, Vol XXV, (No.1), pp.439-452.

Hariyanto, Bayu P. (2018). Pencegahan Dan Pemberantasan Peredaran Narkoba Di Indonesia. J urnal Daulat Hukum, Vol.1, (No.1), pp.201-210.

Rukmana, A. Indra. (2014). Perdagangan Narkotika dalam Perspektif Hukum Pidana Internasional. Jurnal IImu Hukum Legal Opinion, Vol.2,(Vol.1), pp.1-8. 
Jurnal Pembangunan Hukum Indonesia

Volume 1, Nomor 3, Tahun 2019
Program Studi Magister Ilmu Hukum Fakultas Hukum Universitas Diponegoro
Sudanto, A. (2017). Penerapan Hukum Pidana Narkotika di Indonesia. Jurnal Hukum ADIL, Vol.8, (No1),pp.137-161.

Supriyadi. (2015). Penetapan Tindak Pidana Sebagai Kejahatan dan Pelanggaran Dalam UndangUndang Pidana Khusus. Jurnal Mimbar Hukum, Vol.XXVII, (No,3), pp.390-402.

Utami, Ika R. (2014). Kebijakan Aplikasi Dalam Tindak Pidana Narkotika Yang Dilakukan Oleh Anak Di Pengadilan Negeri Semarang. Jumal Law Reform, Vol 9, (No.2), pp.98-109.

Zahra, A. (2017). Penerapan Asas Ultimatum Remedium Dalam Rangka Perlindungan Anak Pecandu Narkoba. J urnal Law Reform, Vol 13, (No.1), pp.18-29.

\section{SUMBER ONLINE}

Berita Sulsel. (2019). Ini Data Terbaru Angka Penyalahgunaan Narkoba di Indonesia. Retrieved From https://beritasulsel.com/baca/ini-data-terbaruangka-penyalahgunaan-narkoba-di-indonesia.

CNN. (2018). BNN Ungkap Lagi Sindikat Narkoba Jalur Lintas Negara. Retrieved From https://www.cnnindonesia.com/nasional/20180 831182454-12-326630/bnn-ungkap-lagisindikat-narkoba-jalur-laut-lintas-negara

Rumah Cemara. (2019). Survei Nasional komsumsi Narkoba di 24 Provinsi Tahun 2017. Retrieved From https://rumahcemara.or.id/book/surveinasional-penyalahgunaan-narkoba-di-34provinsi-tahun-2017/
Liputan6. (2015). BNN: Indonesia Pasar Narkotika Terbesar Di Asia. Retrieved From https://www.liputan6.com/news/read/2363541/ bnn-indonesia-pasar-narkoba-terbesar-di-asia UNODC. (2018). Conclusions And Policy Implications. Retrieved From https://www.unodc.org/wdr2018/prelaunch/WD R18_Booklet_1_EXSUM.pdf

Sepper, Jerry., \& Conery, Ben. (2010). Border violence threatens Americans. Retrieved from http://www.washingtontimes.com/news/2010/a pr/01/violent-mexican-drug-gangspose-risingriskto-ame/.

Sindonews. (2018). 10 Negara Pemasok Narkoba Terbesar di Dunia. Retrieved From https://international.sindonews.com/read/1285 549/45/10-negara-pemasok-narkoba-terbesardi-dunia-1519725612

\section{TESIS \& DISERTASI}

Arianti, V. (2018). Kebijakan Hukum PIdana Terhadap Korban Penyalahgunaan narkotika Di Indonesia. Disertasi Program Doktor IImu Hukum Universitas Gajah Mada.

Dofir, M. (2015). Sistem Peradilan Pidana Dalam Rangka menanggulangi Penyalahgunaan Narkoba. Disertasi Program Doktor IImu Hukum Universitas Air Langga.

Sulistyo, B. (2012). Kebijakan Bimbingan Klien Narkoba Dalam Rangka Pencegahan Penggunaan Tindak Pidana Narkotika. Tesis Magister IImu Hukum Universitas Diponegoro. 